\title{
Biostoning of textile effluent with laccase enzyme
}

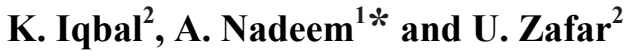 \\ ${ }^{1}$ CSIR Labs, Pakistan \\ ${ }^{2}$ PCSIR Labs, Lahore, Pakistan
}

Received: 31 August 2020

Revised: 22 February 2021

Accepted: 31 March 2021

DOI: https://doi.org/10.3329/bjsir.v56i1.54318

\begin{abstract}
The incessant release of textile effluent comprehending dyes and heavy metals which impacts on aquatic life. Current study used an enzyme to eradicate phenolic compounds and synthetic dyes from textile effluent by an indigenously isolated white rot fungus Pleurotus ostreatus- P1 has been cultured and indicated the utmost laccase activity with synthetic medium; as reacting substrate for dye decolorization. The textile effluent decolorization optimization has been conducted with different concentrations of laccase enzyme, temperature and $\mathrm{pH}$. The $90 \%$ effluent decolorization was obtained by applying response surface methodology (RSM) conditions temperature, crude laccase enzyme and $\mathrm{pH}, 25^{\circ} \mathrm{C}, 13.5 \mathrm{U} / \mathrm{ml}$ and 5 respectively. The predicted values were validated with experimental values that confirms the steadiness of the model.
\end{abstract}

Keywords: Crude enzyme; Textile; Decolorization; RSM; Laccase

\section{Introductio}

The adulteration of water bodies in Pakistan by synthetic dyes from textile is one of the thorniest and global environmental issues. These dyes and their breakdown products disposal into receiving steams is very threatening, toxic and carcinogen potential could lead to derogatory effects on both aquatic ecosystem and eventfully human beings through the food chain. The common practices in developing countries like Pakistan most of the textile industries discharge their daily effluent without or after partial physical/chemical treatments into main water bodies of localities makes the effluent more difficult to treat due to high BOD, COD, colour, $\mathrm{pH}$ and other carcinogenic heavy metals.

These dyes are highly resistant to degradation and its management by adsorption, chemical oxidation, electro-chemistry, membrane filtration, ion exchange, ozonation and phytochemical techniques have some disadvantages due to long processing period, low efficiency and cost prohibitive. There is an insistent need to develop new and effective ecofriendly biological treatment for textile effluent. Recent studies and literature is available on bioremediation by fungi or their enzymes to detoxify and complete mineralization of dye end products. Enzymes (Laccase and peroxidase) decolorized dyes more rapidly and retained its activity even under unfavorable conditions (Arias et al., 2016). I t is biotechnologically important enzyme due to low substrate specificity, culture conditions, fermentation mode and its production may varied due to nutrients and inducers (Birhanl and Yesilada, 2013). Laccase, obtained from different strains and fermentation process, have different dye decolorization ability. It has been reported that laccase derived from Pleuroteus. ostreatus decolorized $70 \%$ malachite green and bromophenol blue also decolorized by laccase produce by Trametes sp.420. Moreover laccase efficiency can be increased by the addition of ABTS mediators because it catalyze phenolic, polyphenol and aromatic amine compounds (Unuofin et al., 2019).

To apply this ecofriendly technique required a number of experiments to optimize different process parameters for 
textile effluent treatment can results time consumption and cost elevation. It is not an easy chore because various factors are involved during effluent decolorization. Several authors have conducted single-factor optimization to evaluate the optimum process conditions. This method is erratic and may lead to misapprehension of results and it does not illustrate the interactive effects among the variables and guarantee the determination of optimal conditions (Mannan et al., 2007). To overcome these limitations a statistical experiment (RSM) was designed for the optimization of process parameters to treat textile effluent.

\section{Materials and methods}

Collection of organism for enzyme production

Pleurotus ostreatus- P1 (laccase enzyme producing organism) was collected for the treatment of textile effluent. Its fruit body was collected from the Horticulture Department, University of Agriculture, Faisalabad, Pakistan. The surface sterilization was conducted with hydrogen peroxide into petri plates contained Kirk medium (Tien and Kirk, 1988) and incubated at $28^{\circ} \mathrm{C}$. (Fig.1).

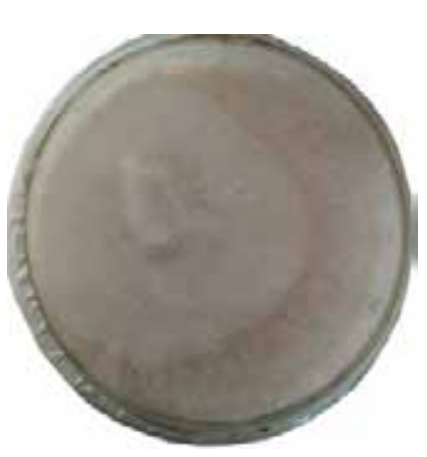

A

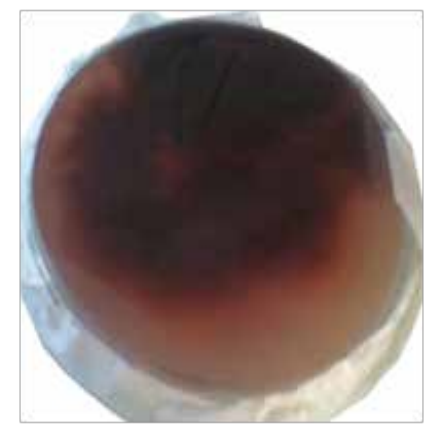

B

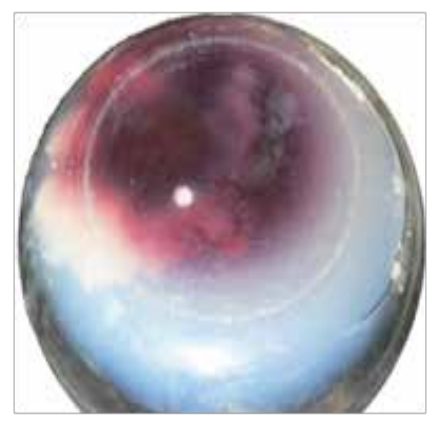

C

Fig 1. (a) Culture plate of Pleurotus ostreatus-P1 (b) Staining by guaiacol (c) Staining by syringaldazine

Response surface methodology (RSM) is a multivariate technique used for developing, improving, and optimizing the process to evaluate the relative significance of different process parameters. It is comprehensively studied in various biotechnology fields i.e optimization of medium composition, fermentation and food processing (Sonica and Kiranjot, 2019). Jadhav et al. (2013) applied the RSM for the decolorization of dyes from water and found encouraging results during their study. However few literatures have been reported for the decolorization of dyes by enzymatic catalysis with RSM technique.

Consequently, the main objective of present study was to investigate the impact of laccase concentration, $\mathrm{pH}$ and temperature on textile effluent decolorization.

\section{Production of laccase by Pleurotus ostreatus- P1}

The mycelia of Pleurotus ostreatus- P1 after seven days of incubation was isolated and stored under controlled environmental conditions at $4{ }^{\circ} \mathrm{C}$ and incubation the synthetic media (ammonium citrate: $10 \mathrm{~g} / 1$; yeast: $0.5 \mathrm{~g} / \mathrm{l}$; glucose: $10 \mathrm{~g} / \mathrm{l} ; \mathrm{KH}_{2} \mathrm{PO}_{4}: 1.0 \mathrm{~g} / \mathrm{l} ; \mathrm{MgSO}_{4}: 0.5 \mathrm{~g} / \mathrm{l} ; \mathrm{KCl}: 0.5$ $\mathrm{g} / \mathrm{l})$ was prepared in $250 \mathrm{ml}$ conical flask by using $150 \mathrm{ml}$ double distilled water and its initial $\mathrm{pH}$ was adjusted at 5.5 with $0.1 \mathrm{M}$ sodium acetate buffer before autoclavation (temp: $121^{\circ} \mathrm{C}$; time: $20 \mathrm{~min}$, pressure:1.5 atm). Hereafter media was inoculated with $4 \mathrm{~mm}$ agar block having seven days old culture of Pleurotus ostreatus-P1 for enhanced laccase production and liquid culture broth of this media was centrifuged at $4000 \mathrm{rpm}$ at $4{ }^{\circ} \mathrm{C}$ for $20 \mathrm{~min}$ to get clear supernatant for enzyme assay. 
Table I. Characteristics of textile effluent

\begin{tabular}{cccc}
\hline Level & $\mathrm{pH}$ & Temperature $\left({ }^{\circ} \mathrm{C}\right)$ & Laccase activity $(\mathrm{U} / \mathrm{ml})$ \\
\hline-1 & 5 & 15 & 7 \\
0 & 6 & 25 & 10.5 \\
+1 & 7 & 35 & 13.5 \\
\hline
\end{tabular}

Table II. The level of variables chosen for decolorization

\begin{tabular}{lcccc}
\hline \multicolumn{2}{l}{ Parameters } & Before treatment & After treatment & NEQS \\
\hline \multicolumn{2}{l}{ Colour $($ Pt-Co) } & 670 & 67 & colorless \\
pH & & 11.4 & 6.45 & $6-10$ \\
BOD & $(\mathrm{mg} / \mathrm{l})$ & 546.32 & 164 & 80 \\
$\mathrm{COD}$ & $(\mathrm{mg} / \mathrm{l})$ & 894.56 & 295 & 150 \\
$\mathrm{TDS}$ & $(\mathrm{mg} / \mathrm{l})$ & 567.0 & 156 & 3500 \\
$\mathrm{TSS}$ & $(\mathrm{mg} / \mathrm{l})$ & 453.0 & 118 & 150 \\
\hline
\end{tabular}

Table III. The Box-Behnken design for three independent variables for color decolorization

\begin{tabular}{cccc}
\hline Run order & $\mathrm{pH}$ & Temperature & Laccase activity \\
\hline 1 & +1 & -1 & 0 \\
2 & -1 & -1 & 0 \\
3 & -1 & 0 & -1 \\
4 & -1 & +1 & 0 \\
5 & 0 & +1 & +1 \\
6 & 0 & -1 & -1 \\
7 & +1 & 0 & -1 \\
8 & +1 & +1 & 0 \\
9 & -1 & 0 & +1 \\
10 & 0 & 0 & 0 \\
11 & 0 & 0 & 0 \\
12 & 0 & 0 & 0 \\
13 & +1 & 0 & +1 \\
14 & 0 & +1 & -1 \\
15 & 0 & -1 & +1 \\
\hline
\end{tabular}




\section{Treatment of textile effluent}

The textile effluent was collected from style textile having the pollutant concentration $\mathrm{pH}$ : 11.4; colour:670 Pt-Co; BOD: $546.32 \mathrm{mg} / \mathrm{l}$; COD: $894.56 \mathrm{mg} / \mathrm{l}$; TDS: $567 \mathrm{mg} / \mathrm{l}$; TSS: 453 $\mathrm{mg} / \mathrm{l}$ were treated by applying the crude laccase enzyme under controlled $\mathrm{pH}$ and temperature (Table II).

Dye decolorization was performed as per experimental design RSM; Laccase concentration (7, 10.5, $13.5 \mathrm{U} / \mathrm{ml}$ ), temperature $\left(15,25,35^{\circ} \mathrm{C}\right)$ and $\mathrm{pH}(5,6,7)$ (Table I). The $\mathrm{pH}$ of the decolorizing solution was adjusted with the addition of di-sodium hydrogen phosphate buffer for $\mathrm{pH} 5,6$ and 7. It was processed in $250 \mathrm{ml}$ Erlenmeyer flask containing phosphate buffer $(25 \mathrm{mM})$, crude enzyme and $50 \mathrm{ml}$ volume of dye effluent as per experimental design RSM for the period of 40 min. The mixture was further stirred for $4 \mathrm{~h}$ on the shaking bath and final absorbance was recorded. A control test was also performed in parallel along with industrial effluent.

Optimization of textile effluent decolorization by response surface methodology (RSM)

Three experimental factors $\mathrm{pH}$, temperature and laccase activity were denoted as $\mathrm{X}_{1}, \mathrm{X}_{2}$ and $\mathrm{X}_{3}$ correspondingly at three different levels $(+1,0,-1)$. These three variables were considered as momentous in dye degradation/decolorization, ranges of which were accomplished from single dye experiment. The temperature and $\mathrm{pH}$ are the factors, affect the reaction rate whereas buffers are the enzyme mediators and surfactants. The low, middle and high levels of each variable were designed as $-1,0,+1$ respectively and listed in Table II and Table III. The three significant variables $\mathrm{X}_{1}$, $\mathrm{X}_{2}, \mathrm{X}_{3}$ and the mathematical relationship of the response $\mathrm{Y}$ to these three variables was approximated by the quadratic model equation as follows:

$\mathrm{Y}=\beta_{0}+\beta_{1} \mathrm{X}_{1}+\beta_{2} \mathrm{X}_{2}+\beta_{3} \mathrm{X}_{3}+\beta_{11} \mathrm{X}_{12}+\beta_{22} \mathrm{X}_{22}+\beta_{33} \mathrm{X}_{32}+\beta_{12} \mathrm{X}_{1} \mathrm{X}_{2}+$ $\beta_{13} X_{1} X_{3}+\beta_{23} X_{2} X_{3}$

where Y - predicted response; $\beta_{0}$ - constant; $\mathrm{X}_{1}-\mathrm{pH} ; \mathrm{X}_{2}$ temperature; $\mathrm{X}_{3}$ - laccase activity; $\beta_{1}, \beta_{2}$ and $\beta_{3}$ linear co efficient; $\beta_{11} \beta_{22} \beta_{33}$-quadratic coefficient; $\beta_{12} \beta_{13} \beta_{23}$-crosscoefficient.

The preset ranges of independent variables for dye decolorization optimization:Laccase concentration (7, $10.5,13.5 \mathrm{U} / \mathrm{ml})$, temperature $\left(15,25,35^{\circ} \mathrm{C}\right)$ and $\mathrm{pH}$ $(5,6,7)$ (Table I).

A total number of 15 experiments were obligatory to determine the 10 coefficient in the quadratic model equation.
In this study, experiments were run in duplicate i.e. 30 experiments were carried out to calculate approximately 10 coefficients for the decolorization of dyes. Design permits to establish the linear and quadratic models, determine the accuracie by comparing lacks of fit of model and coefficient of determination $\mathrm{R}^{2}$. The statistical analysis were performed using multiple regression and one way 'Analysis of Variance (ANOVA).

The decolorization capacity $(\mathrm{Qe})$ and removal percentage of effluent were determined by using the following equations.

$$
\begin{gathered}
\mathrm{Qe}=\frac{\mathrm{Co}-\mathrm{Ce}}{\mathrm{W}} \times \mathrm{V} \\
\mathrm{R}(\%)=\frac{\mathrm{Co}-\mathrm{Ce}}{\mathrm{Ce}} \times 100
\end{gathered}
$$

where Qe $(\mathrm{mg} / \mathrm{g})$ was the capacity of dye degradation, Co $(\mathrm{mg} / \mathrm{l})$ was the initial concentration and $\mathrm{Ce}(\mathrm{mg} / \mathrm{l})$ was the concentration at time t, V (1) was the initial volume of dye solution and $\mathrm{W}(\mathrm{g})$ was the amount of enzyme used.

\section{Analytical techniques}

\section{Laccase assay}

Laccase activity was determined by enzymatic oxidation of syringaldazine spectrophotometrically at $525 \mathrm{~nm}(\epsilon$ $525=65000 / \mathrm{M} / \mathrm{cm})$. The assay mixture has $850 \mu \mathrm{l}$ of 0.1 $\mathrm{M}$ sodium citrate ( $\mathrm{pH} 5), 100 \mu$ l of syringaldazine $(0.1$ $\mathrm{mM}$ ) and $50 \mu \mathrm{l}$ of fungal broth supernatant. One unit of enzyme activity was defined as the amount of enzyme which caused an increase of one in the absorbance per min under assay condition (Li et al., 2008). Similarly laccase activity was also determined by guaiacol oxidation at 450 $\mathrm{nm}(\epsilon=12100 / \mathrm{M} / \mathrm{cm})$. The reaction mixture contained 3 $\mathrm{ml}$ acetate buffer (10 mM, pH: 5), $1 \mathrm{ml}$ guaiacol (2 mM) and $1 \mathrm{ml}$ supernatant and $\mathrm{U} / \mathrm{ml}$ was calculated.

\section{Effluent parameters}

The effluent samples were treated as per experimental design (RSM) and their characteristics were analyzed. The samples were collected from experimental flask and determined the color, $\mathrm{pH}$, COD, BOD, TDS and TSS. 


\section{Statistical analysis}

In order to reduce the errors during dye decolorization/degradation and enzyme assay each experiment was conducted in triplicate under identical conditions and then mean and standard error (S.E) values were obtained. S.E has been displayed as a Y-errors bar in figures by using MS-2010 along with color decolorization by RSM was applied by using software Mintab.16.

\section{Results and discussion}

Laccase was a unique enzyme; its production can be enhanced for industrial scale by optimization of physiologicaland nutritional synthetic media.The foremost cause of screening fungus Pleurotus ostreatus-P1 for laccase production was due to its importance as an efficient source of laccase (Alba et al., 2019). The presence of laccase was confirmed by the formation of reddish brown and dark purple zone due to the oxidation of Guaiacol and Syringaldazine (Wang et al., 2008).

The white rot fungi (enzymes) have the ability to decolorize the effluent color which was proportional to the removal of chromogen.The decolorization percentage in present study was 90 at optimized temperature and $\mathrm{pH}$. In addition decolorization percentage was increased as the quantity of laccase enzyme increased.Similar observations have been found on co-relationship between ligninolytic enzymes and textile dye decolorization (Patel et al., 2009). It has been reported that concentration of dye effect the removal percentage of color by laccase enzyme. It was clear from these results white rot fungi (Basidiomycetes) along with other species have the ability to reduce or decolorize the color of dyes in proficient form. It was also noted that pure laccase enzyme did not decolorize the effluent completely due to absence of mediators.

In textile industry, different process including caustic scouring, bleaching, mercerization and dyeing are running parallel that impact on the $\mathrm{pH}$ of effluent. $\mathrm{pH}$ was a requisite parameter for biological treatment of effluent because microbes mechanized between pH 6-8. During this study the $\mathrm{pH}$ of the sample meets the NEQS after treatment, whereas effluent showed that the highly basic salts has been used in dying process (Table II).

The total suspended solids (TSS) based on the nature of chemical and physical process continuing in the industry. These are not filter from the common filter paper and hinder the microbial activity, which ultimately reduce the mechanism of decolorization of dyes.

Presently the decolorization was enhanced by the reduction of TDS up to $72.5 \%$. It depicted that reduction in TDS means white rot fungi producing enzymes have the proficiency to lessen the dye color in more precise way than chemical process. The similar observation has been found in case of TSS due to the same nature of inorganic salts. These are aesthetically inadequate for human besides the ecosystem (Patel et al., (2009).
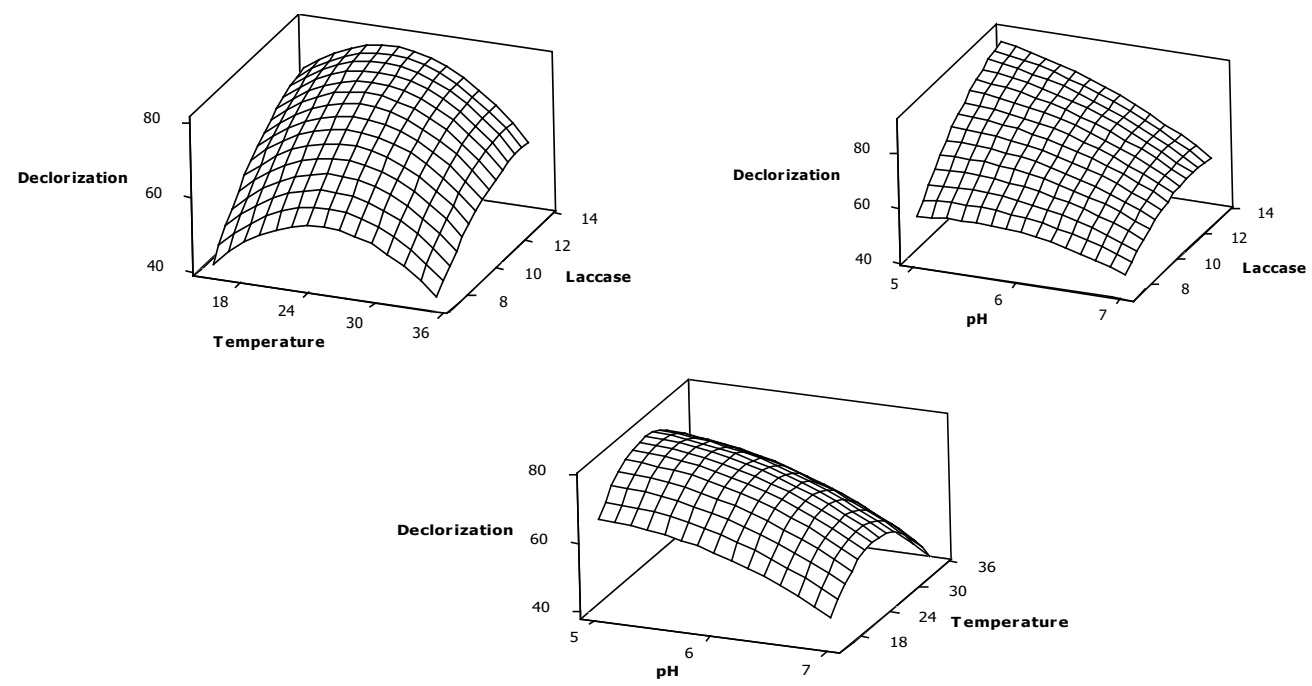

Fig. 2. Decolorization of textile effluent by response surface methodology (RSM) under experimental conditions of pH, temperature and laccase concentration 
Table IV. Experimental design and response of Box-Behnken for decolorization

\begin{tabular}{cccccc}
\hline Run & $\mathrm{pH}$ & $\begin{array}{r}\text { Temperature } \\
\left({ }^{\circ} \mathrm{C}\right)\end{array}$ & $\begin{array}{c}\text { Laccase activity } \\
(\mathrm{U} / \mathrm{ml})\end{array}$ & Observed values & $\begin{array}{c}\text { \% decolorization } \\
\text { Predicted values }\end{array}$ \\
\hline 1 & 7 & 15 & 10.25 & 45.30 & 46.73 \\
2 & 5 & 15 & 10.25 & 66.78 & 66.02 \\
3 & 5 & 25 & 7.00 & 53.21 & 55.92 \\
4 & 5 & 35 & 10.25 & 63.09 & 61.66 \\
5 & 6 & 35 & 13.50 & 57.43 & 59.38 \\
6 & 6 & 15 & 7.00 & 43.23 & 41.28 \\
7 & 7 & 25 & 7.00 & 45.76 & 46.29 \\
8 & 7 & 35 & 10.25 & 39.65 & 40.41 \\
9 & 5 & 25 & 13.50 & 90.54 & 90.01 \\
10 & 6 & 25 & 10.25 & 72.87 & 72.87 \\
11 & 6 & 25 & 10.25 & 72.87 & 72.87 \\
12 & 6 & 25 & 10.25 & 72.87 & 59.09 \\
13 & 7 & 25 & 13.50 & 61.80 & 41.28 \\
14 & 6 & 35 & 7.00 & 42.56 & 70.06 \\
15 & 6 & 15 & 13.50 & 68.78 & \\
\hline
\end{tabular}

Table V. ANOVA results for textile waste decolorization quadratic response surface model fitting

\begin{tabular}{lccccc}
\hline Sources & $\begin{array}{l}\text { Degrees of } \\
\text { freedom }\end{array}$ & Sum of square & $\begin{array}{l}\text { Mean of } \\
\text { squares }\end{array}$ & F-value & p-value \\
\hline Regression & 9 & 3004.44 & 333.83 & 53.18 & 0.000 \\
Linear & 3 & 1978.96 & 659.65 & 105.08 & 0.000 \\
Square & 3 & 882.69 & 294.23 & 46.87 & 0.000 \\
Interaction & 3 & 142.79 & 47.60 & 7.58 & 0.026 \\
Residual & 5 & 31.39 & 6.28 & \\
error & 3 & 31.39 & 10.46 & & \\
Lack of fit & 2 & 0.00 & 0.00 & & \\
Pure error & 14 & 3035.82 & & & \\
Total & & & & & \\
\hline
\end{tabular}
$R^{2}-98.97 \% R^{2}$ (pred)- $83.46 \% R^{2}$ (adj)- $97.11 \%$

Table VI. Regression co-efficient of the model for dye decolorization

\begin{tabular}{lllll}
\hline Terms & Coef & SE Coef & $\mathrm{T}$ & $\mathrm{p}$ \\
\hline Constant & 72.8700 & 1.4465 & 50.375 & 0.000 \\
$\mathrm{X}_{1}$ & -10.1388 & 0.8858 & -11.446 & 0.000 \\
$\mathrm{X}_{2}$ & -2.6700 & 0.8858 & -3.014 & 0.030 \\
$\mathrm{X}_{3}$ & 11.7238 & 0.8858 & 13.235 & 0.000 \\
$\mathrm{X}_{12}$ & -4.6688 & 1.3039 & -3.581 & 0.016 \\
$\mathrm{X}_{22}$ & -14.4962 & 1.3039 & -11.118 & 0.000 \\
$\mathrm{X}_{32}$ & -5.3738 & 1.3039 & -4.121 & 0.009 \\
$\mathrm{X}_{1} \mathrm{X}_{2}$ & -0.4900 & 1.2527 & -0.391 & 0.712 \\
$\mathrm{X}_{1} \mathrm{X}_{3}$ & -5.3225 & 1.2527 & -4.249 & 0.008 \\
$\mathrm{X}_{2} \mathrm{X}_{3}$ & -2.6700 & 1.2527 & -2.131 & 0.086 \\
\hline
\end{tabular}


COD and BOD are the upright indicator of degradable material which reasons of aesthetic smell the surrounding. In this study the reduction of BOD and COD was $70 \%$ and $67 \%$ respectively and reduction in BOD and COD enhanced as the concentration of laccase enzyme augmented with suitable temperature and $\mathrm{pH}$. It depicted that the activity of enzyme increased when the $\mathrm{pH}$ of medium will be 5 and temperature will $25^{\circ} \mathrm{C}$. So it can be concluded that laccase enzyme reduce the color and other pollutant concentrations according to the lines of NEQS.

Decolorization of textile dye by whole culture broth of Pleurotus ostreatus-P1

The laccase produced by Pleurotus ostreatus-P1 was used to evaluate the oxidation of dye at different temperatures, $\mathrm{pH}$ and decolorization was noted at different time intervals (Fig 2).

A Box-Behnken design under RSM was used to analyze the interactive impact of $\mathrm{pH}$, temperature and laccase units on decolorization. The base point for the design was selected from single parameter study in decolorization process under controlled conditions.

The selected levels of independent variables used in experiment are given in Table IV.Fifteen experimental runs were carried out according to Box-Behnken design three variables; $\mathrm{pH}$, temperature and laccase units. Various combinations of three variables and the decolorization percentage of dye in each case are presented in Table IV. The quadratic equation was fitted to the above data by using multiple linear regressions by software design expert techniques.

$\mathrm{Y}=-485.122+102.575 \mathrm{X}_{1}+10.0475 \mathrm{X}_{2}+28.3214 \mathrm{X}_{3}-7.71250 \mathrm{X}_{1}{ }^{2}$ - $0.170125 \mathrm{X}^{2}{ }^{2}-0.488776 \mathrm{X}_{3}{ }^{2}+$ $0.0675000 \mathrm{X}_{1} \mathrm{X}_{2}-1.80000 \mathrm{X}_{1} \mathrm{X}_{3}-0.1428574 \mathrm{X}_{2} \mathrm{X}_{3}$

The goodness of the model was checked by the coefficient of determination $\mathrm{R}^{2}$ and adjusted $\mathrm{R}^{2}$ (multiple correlation co-efficient $\mathrm{R})$. The value of adjusted $\mathrm{R}^{2}(97.11 \%)$ suggest that the total variation of $97.11 \%$ of decolorization is accredited to the independent variable and only $0.45 \%$ of the total variation could not be defined by this model. The values of adjusted $\mathrm{R}^{2}$ near to 1 explain the better correlation between the experimental and predicted values. The predicted $\mathrm{R}^{2}$ of $83.46 \%$ was in realistic form with adjusted $\mathrm{R}^{2}$ of $97.11 \%$ between the experimental and predicted values of decolorization. The corresponding coefficients are significant when the t-values are smaller whereas the p-values are larger as are presented in Table-VI. In this case coefficient $X_{1}, X_{2}$ and $X_{3}$ were examined to be highly important model terms. The coefficient of interaction terms
$\left(\mathrm{X}_{2} \mathrm{X}_{3}\right.$ and $\left.\mathrm{X}_{1} \mathrm{X}_{3}\right)$ of temperature and laccase units was found to be highly significant. The decolorization results of reactive dyes and its analysis of variance are presented in Table-V. It defined the quadratic model by one way ANOVA and the calculated values of $F(50.37)$ and low probability $(\mathrm{F}=0.0001)$ show that the model was significant. It was also noted from Table VI the coefficient for the square effect $(p=0.0001)$ and interaction effects of all parameters were highly significant when compared with linear effects.

The laccase produced by Pleurotus ostreatus was used to evaluate the oxidation of dye at different temperatures and $\mathrm{pH}$ value. The crude laccase from Pleurotus ostreatus decolorize anthraquinone more efficiently than azo dyes. The laccase from Pleurotus ostreatus causes dyes decolorization because of dyes structure which results in difference in substrates specificity.Similar results were obtained from laccases from T. hirsuta, T. versicolor and Polyporus pinisitus. When an azo dye was oxidized by a laccase, it cleaves the azo linkage of phenoxy radicles and release molecular nitrogen. As a result, the decolorization of azo dyes occurs and toxic aromatic amine was excluded.

The application of response surface technology to examine the effect of laccase from Pleurotus ostreatus, $\mathrm{pH}$ and temperature on decolorization was completed. A quadratic equation was established to demonstrate the relationship between decolorization percentage and three variables of the design. The experimental values were in line with predicted values and the model was highly significant with the correlation coefficient. The limitation for the use of Pleurotus ostreatus cultures for decolorization was the acidic $\mathrm{pH}$ range for the activity which was similar to other white rot fungi. Effluents from textile industry always contain mixed dyes and mostly show high $\mathrm{pH}$ in the presence of auxiliary dyeing compounds which are not favored to the culture liquid and purified laccase from white rot fungi in term of dye decolorization because low $\mathrm{pH}$ was essential in fungal growth medium for their metabolic activity. However, Pleurotus ostreatus culture liquid was able to decolorize not only the synthetic dye solutions at acidic $\mathrm{pH}$ but also synthetic dye both at high $\mathrm{pH}$ and low temperature. The Box-Behnken and central composite experiment designs were applied in decolorization by laccase from $P$. sajor-caju and $T$. pubescens respectively with the addition of HBT as mediator and biodegradation of reactive dye (Verofix Red) by P. chrysosporium. The Box-Behnken results revealed that decolorization obtained up to $90 \%$ when the temperature, crude laccase enzyme and $\mathrm{pH}$ were $25^{\circ} \mathrm{C}, 13.5 \mathrm{U} / \mathrm{ml}$ and 5 respectively. 
The $\mathrm{pH}$ of solution was an imperative element because it impacts on the chemical properties of dye molecules and on mechanism of adsorption process. It takes part on activity of functional group on adsorbent surface as well as competition of dye molecules for bonding with hydrogen molecules of adsorbents. In this study the amount of dye removal was analyzed to optimize the $\mathrm{pH}$ of solution under the range of $\mathrm{pH}$ 5-7 and fixed concentration of crude laccase enzyme $(13.5 \mathrm{U} / \mathrm{ml})$ for the period of $40 \mathrm{~min}$ under $25^{\circ} \mathrm{C}$ temperature; results obtained are presented in Fig. 3a. As seen from Fig. 3a removal of dye concentration was increased with decreasing the initial $\mathrm{pH}$ of solution from 5-7 and maximum removal percentage was attained under the $\mathrm{pH} 5$. It is due to the difference of redox potential of dyes with the active site of laccase enzyme. The redox potential was an important factor and the production of laccase from different fungi has
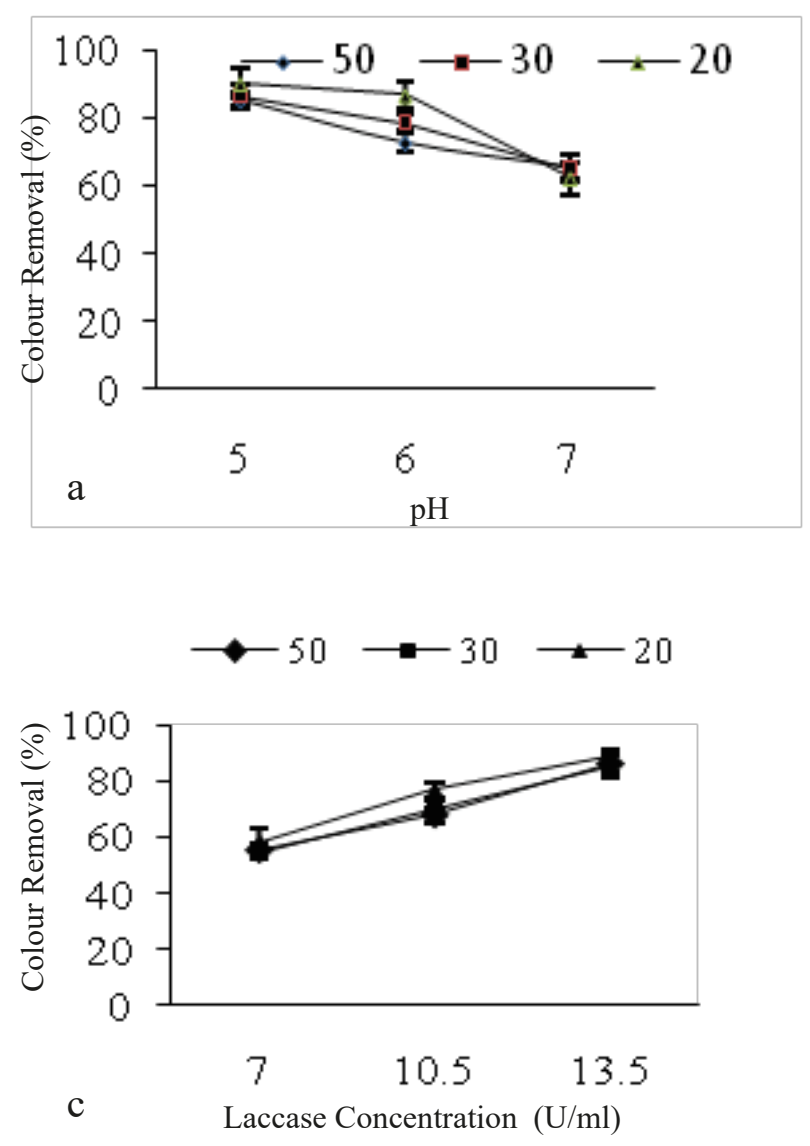

different redox potential. The decolorization with laccase enzyme depends on the enzyme source (species) chemical structure of dye and reaction conditions (temperature, crude laccase enzyme concentration, $\mathrm{pH}$ and time). The lesson in color due to $\mathrm{pH}$ was retained on the same pattern in all concentration of dye solutions $(20,30,50 \mathrm{mg} / \mathrm{l})$ in this study. These results are in agreement with Yesilada et al. (2014).

The impact of temperature on decolorization of dye by crude laccase enzyme was investigated under three temperatures namely 5,15 and $25^{\circ} \mathrm{C}$. When temperature of incubation was increased the decolorization of dye was also raised up to certain limit and then decline in their behavior due to the activity of laccase enzyme inhibited at higher and lower temperature.The highest removal was attained at $25^{\circ} \mathrm{C}, 95.4 \%, 94.86 \%, 93.6 \%$ more than $5^{\circ} \mathrm{C}$ for $50,30,20$ $\mathrm{mg} / \mathrm{l}$ respectively. Most of white rot fungi (WRF) enzymes
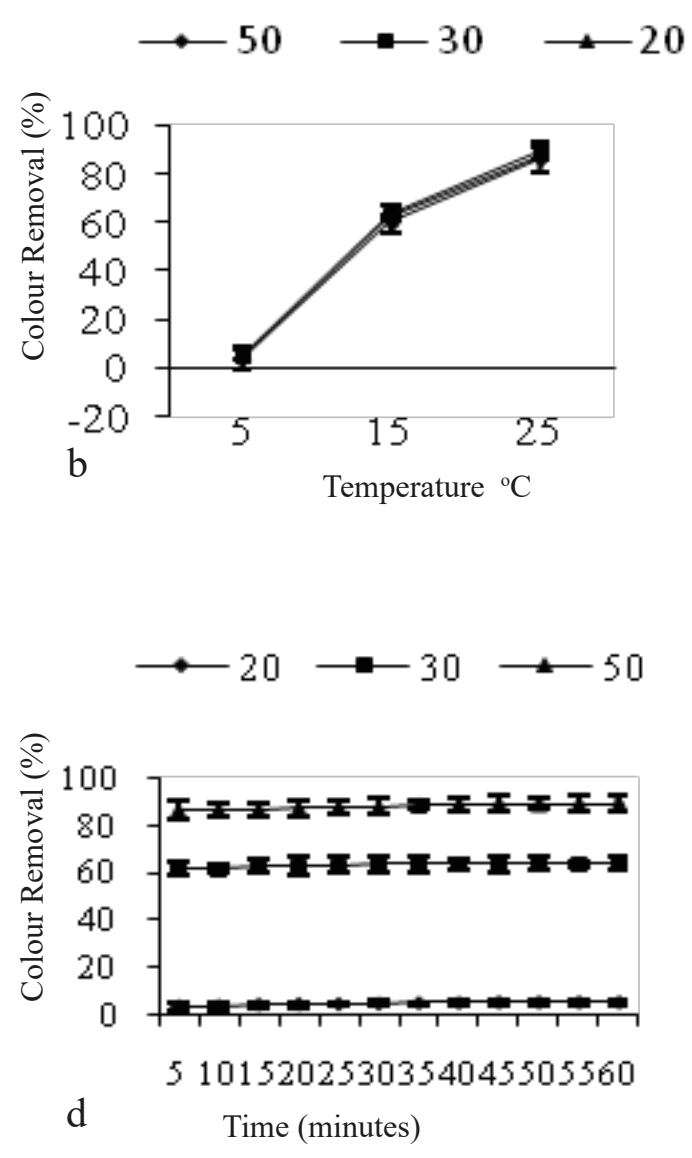

Fig 3. Effect of different factors on color removal (a) pH (b) Temperature (c) Laccase concentration (d) Time 
having optimum temperature for colour removal ranged from $25-37^{\circ} \mathrm{C}$ for different dye stuffs. It has been cited in literature WRF like P.chrysoporium and Corious versicolor give maximum dye removal at $35^{\circ} \mathrm{C}$, whereas below 25 and above $40^{\circ} \mathrm{C}$ inhibit the fungal growth and lignolytic enzymes production. Liu et al. (2013) reported that the purified and crude laccase enzyme have been found an effective dye removal agent. Similar observations have been found in this study (Fig 3b).

To examine the impact of laccase enzyme amount on dye decolorization, different amounts of crude enzyme were exercised to inoculate the triplicate decolorization flasks, were incubated for stipulated time period under optimized $\mathrm{pH}(5)$ and temperature $\left(25^{\circ} \mathrm{C}\right)$. The amount of enzyme affects the decolorization percentage positively and it increased as the concentration of enzyme increased depicted in Fig.3c but sometimes increase in enzyme size/ amount reduce the decolorization due to early exhaustion of nutrients. The percentage removal of dye was maximum by $13.5 \mathrm{U} / \mathrm{ml}$, which was $34.8 \%$ more than $7 \mathrm{U} / \mathrm{ml}$ for $20 \mathrm{mg} / 1$ effluent. Similarly $21.4 \%, 17.34 \%$ and $13.4 \%$ more than $10.5 \mathrm{U} / 1$ for 50,30 and $20 \mathrm{mg} / 1$ respectively. In addition, similar to our finding Kumar et al. (2010) reported $4 \%$ (v/v) optimum inoculum density for textile waste water decolorization. It was also stated in literature laccase exhibited the promising and great potential for decolorization of dyes in waste effluent (Birhanl and Yesilada, 2013).

In order to optimize the time for the decolorization of synthetic dye solution $(20 \mathrm{mg} / \mathrm{l})$ by laccase enzyme under optimize $\mathrm{pH}(5)$, laccase concentration $(13.5 \mathrm{U} / \mathrm{ml})$ and temperature $\left(25^{\circ} \mathrm{C}\right)$. It was noted that maximum decolorization occurred within first $40 \mathrm{~min}$, thereafter the equilibrium was attained. The decolorization rate depended on the source and concentration of enzyme, structure of dye, time for action, $\mathrm{pH}$ of medium and temperature. The peak reduction in color in initial stage may be the maximum utilization of laccase enzyme (Fig.3d).

\section{Conclusion}

The laccase enzyme was isolated from local strainPleurotus ostreatus- P1; enhanced its production by synthetic media. Enzyme concentration was optimized by RSM and check its efficiency for the decolorization of textile effluent. It was found Laccase has the potential to degrade the aromatic and other substrate present in effluent. It was concluded that $13.5 \mathrm{U} / \mathrm{ml}$ of laccase enzyme caused $90 \%$ color removal from textile effluent. So this can also be applied for biostoning in textile industry.

\section{References}

Alba B, Juana R, Vania B, Sonia M, Ligia O M, Andrew SB, Maria A and Manuel H (2019), Decolorization and detoxification of textile dyes using a versatile Streptomyces laccase-natural mediator system, Sau Jour of Biologi Sci. 26: 913-920. DOI: org/10.1016/j.sjbs.2018.05.020

Arias ME, Blanquez A, Hernández M, Rodriguez J, Ball AS, Jimenez-Morillo NT, González-Vila FJ and Gonzalez-Perez J A (2016), Role of a thermostable laccase produced by Streptomyces ipomoeae in the degradation of wheat straw lignin in solid state fermentation, J Anal Appl Pyrol. 122: 202-208. DOI: org/10.1016/j.jaap.2016.09.023

Birhanl E and Yesilada O (2013), The utilization of lignocellulose wastes for laccase production under semisolid-state and submerged fermentation conditions, Turk J Biol. 37: 450-456.

Jadhav SB, Surwase SN, Phugare SS and Jadhav J P (2013), Response surface methodology mediated optimization of Remazol Orange decolorization in plain distilled water by Pseudomonas aeruginosa BCH, Int J Environ Technol. 10: 181-190.

Kumar VV and Rapheal VS (2010), Induction and Purification by Three-Phase Partitioning of Aryl Alcohol Oxidase (AAO) from Pleurotus ostreatus, Appl Biochem Biotech. 163: 423-432.

Li A, Zhu Y, Liang X, Wenqing Z and Xingjun T (2008), Comparative study on the determination of assay for laccase of Trametes sp., Afri $J$ of Biochem Res. 2: 181-183. DOI: org/10.5897/AJBR.9000064

Liu ST, Huang J, Ye Y, Zhang A, Pan L and Chen X G (2013), Microwave enhanced Fenton process for the removal of methylene blue from aqueous solution, Chem Engin J. 215: 586-590. DOI: org/10.1016/j.cej.2012.11.003

Mannan S, Fakhrul-Razi A and Alam MZ (2007), Optimization of process parameters for the bioconversion of activated sludge by 
Penicillium corylophilum using response surface methodology, $J$ Environ Sci. 19: 23-28. DOI: org/10.1016/S1001-0742(07)60004-7

Patel H, Gupte A and Gupte S (2009), Biodegradation of Fluoranthene by basidiomycetes fungal isolates Pleurotus ostreatus HP-1, Appl Biochem Biotechnol. 157: 367-376.

Sonica S and Kiranjot S (2019), Response surface based optimization of laccase production from Bacillus sp., MSK-01 using fruit juice waste as an effective substrate, Heliy. 5: 1718. DOI: org/10.1016/j.heliyon.2019.e01718

Tien M and Kirk TK (1988), Lignin peroxidase of Tien and Phanerochaete chrysosporium. Meth. Enzymol. 161: 238-249. DOI: org/10.1016/0076-6879(88)61025-1
Unuofina JO, Moubasherc HA, Okoha A I and Nwodoa UU (2019), Production of polyextremotolerant laccase by Achromobacter xylosoxidans HWN16 and Citrobacter freundii LLJ16, Biotech Rep. 24:1-10.

Wang P, Hu X, Cook S, Begonia M, Lee KS and Hwang HM (2008), Effect of culture conditions on the production of ligninolytic enzymes by white rot fungi Phanerochaete chrysosporium (ATCC 20696) and separation of its lignin peroxidase, Word $J$ of Microbiol and Biotech. 24: 2205-2212.

Yesilada O, Birhanl E, Ercan S and Ozmen N (2014), Reactive dye decolorization activity of crude laccase enzyme from repeated-batch culture of Funalia trogii, Turk J Biol. 38: 103-110. 